\title{
PORCINE STRESS SYNDROME (PSS) AND RYANODINE RECEPTOR 1 (RYR1) GENE MUTATION IN EUROPEAN WILD PIG (Sus scrofa ferus)
}

JOVANOVIĆ S, TRAILOVIĆ RUŽICA, SAVIĆ MILA and SARAČ M

Faculty of Veterinary Medicine, Belgrade

(Received 9. January 2005)

Expression of the stress syndrome (PSS) in European wild pig was evaluated by Halothane test and tested animals were typed by PCR/RFLP test for C/T mutation at nt 1843 in RYR1 gene.

A total of 56 animals, at the age of 5 months, weighing $20 \mathrm{~kg}$ average, were tested. Hal+ (MHS-malignant hyperthermia susceptible) phenotype was revealed in 6 pigs, 47 animals expressed $\mathrm{Hal}$ - (MHN - malignant hyperthermia resistant) phenotype, while 3 animals showed no response to administration of 3\% halothane after 5 minutes and they were marked as Halr (halothane resistant) phenotypes. Genotyping of 56 wild pigs revealed that the tested population was homozygous for the normal C/C allele at RYR1 locus.

The results obtained by halothane test show that expression of the PSS in wild pigs is modulated and influenced by factors other then RYR1 genotype.

Key words: wild pigs, PSS, halothane test, RYR1 locus

\section{INTRODUCTION}

Breeding of domesticated animals for food production historically was directed to increase productive performances. This way highly selected, meattype pig breeds were developed. Only after the productivity and/or production cost was affected, the selection of animals towards resistance to diseases and ambiental changes was considered. Intensive pig breeding suffered greatly from the manifestation of PSS (porcine stress syndrome), defined as an inherited, autosomal recessive trait in pigs manifested as progressive malignant hyperthermia and/or sudden deaths developed after exposition of animals to mild to moderate stress conditions or triggered by some drugs. The condition affects muscle tissue after death resulting in pale, soft, exudative meat (PSE) evidenced on the slaughtere line.

Evaluation of the genetic etiology of the syndrome revealed that halothane sensitivity in pigs is highly associated with some genetic markers in pigs. It was defined that halothane induced malignant hyperthermia $(\mathrm{MH})$ is controlled by recessive autosomal allelic genes on $\mathrm{HAL}$ locus. Following the investigation of the HAL locus it was assembled to the s(A-O)-GPI-HAL-H-A1BG-PGD linkage group on the porcine chromosome 6 (Juneja et al., 1983, Jerle et al., 1990) it was 
considered that the causative structural change in calcium ion release channel/ryanodine receptor 1 encoded by RYR1 loci allelic genes is responsible for the development of $\mathrm{MH}$ in pigs as well as in humans and dogs. RYR1 locus was assigned as a candidate gene for HAL.

PSS is considered to be the animal model for the evaluation of equivalent conditions in humans. Furthermore, the condition was considered until recently to be a characteristic of domesticated pigs. Only after the altered hyperthermic reaction to halothane anaesthesia in wild pigs was observed, the complexity of the disturbance was revealed. After comparative studies of halothane susceptibility in different commercial pig breeds it was revealed that the expression of $\mathrm{HAL}^{+}$ phenotype is very frequent in some breeds (Jovanović et al., 1987; Gahne et al., 1985).

Although PSS is significantly more frequent in commercial pigs, data describing the developed MH/PSE in wild pigs are lacking. Therefore evolution and/or domestication in inducing progression of genetic disturbances like PSS is highly questionable.

\section{MATERIAL AND METHOD}

A total of 56 animals, 5 months old, weighing around $20 \mathrm{~kg}$ were tested for PSS by Halothane challenge test (Eikelenboom and Minkema, 1974).

Blood samples were collected into sterile tubes containing K3EDTA, as anticoagulant. DNA isolation was performed upon PCR protocol described by Higushi (1989).

PCR products were stored at $4^{\circ} \mathrm{C}$ until RFLP analyses. PCR products were cut into fragments at the mutation site and at a control site common to the normal and mutated gene. The obtained samples were digested for $2 \mathrm{hr}$ with $4 \mathrm{U}$ of BsiHKAl restriction enzyme (BioLabs, USA). Restriction digests were further separated by agarose gel electrophoresis in Tris-borate/EDTA buffer, pH 8.0 (Vogeli et al., 1994; O’Brien et al., 1993).

The distribution of halothane allelic frequencies were calculated and compared with the results of PCR/RFLP test.

\section{RESULTS AND DISCUSSION}

Healthy, captured wild pigs of both sexes were inhaled with $3 \%$ halothane through inhalation masks during 5 minutes. Halothane challenge test revealed that 6 out of 56 wild pigs expressed halothane induced stress reaction developing symptoms of malignant hyperthermia (MHS - malignant hyperthermia susceptible), while 3 animals were resistant to halothane anaesthesia (Halr halothane resistant phenotypes). Non-reactive animals were further submitted to prolonged (10 minutes) administration of halothane in concentration of $5 \%$ and responded by induction of narcoses (Figure 1).

The halothane administration showed that the phenotypes of tested animals were $\mathrm{Hal}+, \mathrm{Hal}-$ and $\mathrm{Halr}, 11 \%, 84 \%$ and $5 \%$, respectively. 
Close correlation between the halothane response and allelic genes distributed within calcium release channel gene was evidenced by McLennan and Phillips (1992), O’Brien et al. (1993), Schmolzl (1993) and Vogeli et al. (1994). Mutation at nt 1843 is a causative agent for substitution of arginine 615 with cysteine in the sequence of skeletal muscle calcium release channel protein in commercial pig breeds (Vogeli et al., 1994, Sarač et al, 1996). Linkage analyses indicated RYR1 gene as a candidate gene for Hal in pigs.

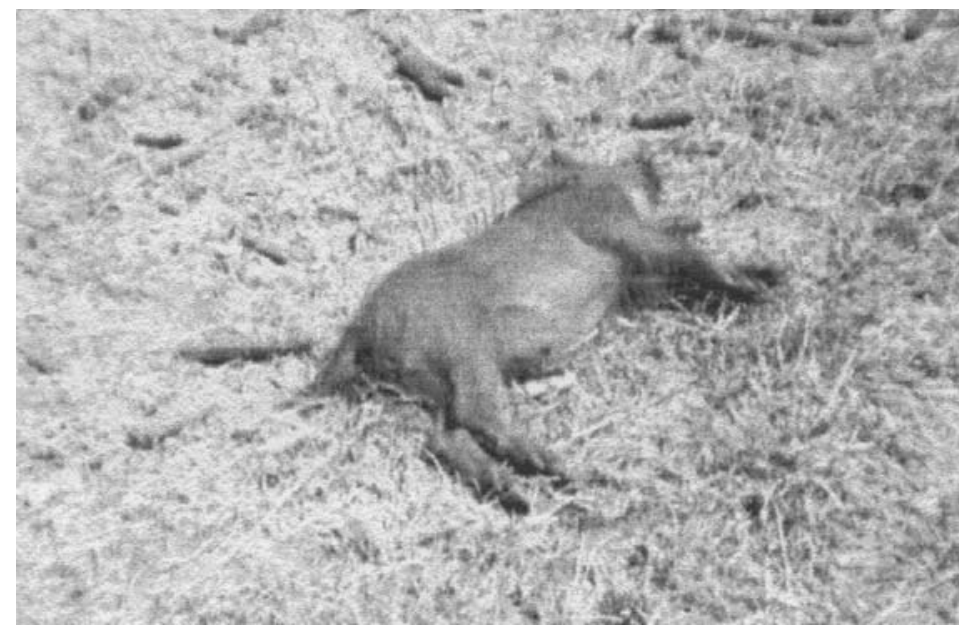

Figure 1. Halothane anaesthesia in wild pig

Analyses for $\mathrm{C} / \mathrm{T}$ missence mutation at RYR1 locus revealed that all tested wild pigs were of normal CC genotype at nt 1843. The tested population of wild pigs has been homozygous for the normal RYR1 allele upon results obtained by PCR/RFLP test (Figure 2).

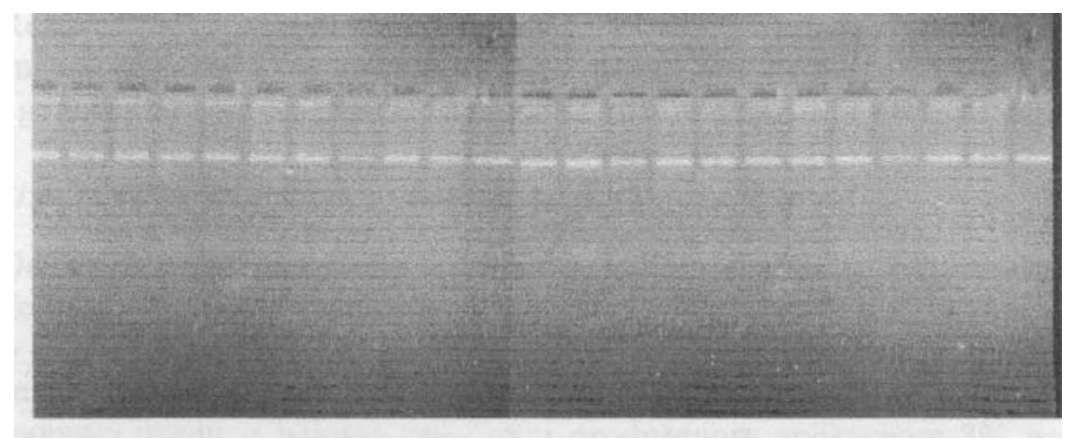

Figure 2. Results of PCR/restriction endonuclease test for C-T mutation at nt 1843 in RYR1 gene 
Comparison of halothane phenotypes with RYR1 genotypes in the tested population of wild pigs did not confirm the theory of the monogenetic aetiology of PSS.

\section{CONCLUSIONS}

Having in mind that the missence mutation in calcium ion channel ryanodine receptor gene (RYR1) was considered responsible for expression of PSS and $\mathrm{MH}$ in humans and in domestic pigs the results obtained show that there can be other factors which influence the malignant stress reaction in wild pigs, therefore probably in the domesticated pig population as well. The multifactorial origin of $\mathrm{MH}$ in pigs can be theoretically emphasized.

In spite of the wide spread believe that PSS arose during domestication and selection of pigs for meat the presence of halothane induced $\mathrm{MH}$ in wild pig speaks-up for a more complex evolutive event. The complexity of PSS is further more underlined by the fact that the sequence containing both Hal gene and RYR1 gene on porcine chromosome 6 is highly conserved (Rempel et al., 1993). It is questionable weather the PSS/MH in domestic pigs evolved through selective breeding programmes.

AKNOWLEGMENT:

This researche was supported by Ministry of Science and Technology of Republic of Serbia, grant 1830.

Address for correspondence:

Slobodan Jovanović

Department of Animal Breeding and Genetics

Faculty of Veterinary Medicine

Bul JNA18, 11000 Belgrade

Serbia \& Montenegro

e-mail: stocarstvo@vet.bg.ac.yu

\section{REFERENCES}

1. Eikelenboom G, Minkema D, 1974, Prediction of pale, soft, exudative muscle with non-lethal test for the halothane-induced porcine malignant hyperthermia syndrome, Tiejdschr Diergeneeskd, $99,421-7$

2. Gahne B, Juneja RK, 1985, Prediction of the halothane (Hal) genotypes of pigs by deducing Hal, Phi, $\mathrm{PO} 2$, Pgd haplotypes of parents and offspring: results from large-scale practice in Swedish breeds, Anim Blood Groups Biochem Genet, 16, 265-83

3. Higushi R, 1989, Rapid, efficient DNA extraction for PCR from cells or blood, Amplifications- $A$ Forum for PCR Users 2, 1'3

4. Jerle M, Archibald AL, Dalens M, Gellin J, 1990. Localization of PGD and TGF beta-1 to pig chromosome 6q, Anim Genet, 21, 411-7.

5. Jovanović S, Gagrčin M, Nikolić $P, 1987$, Polimorfizam fosfoheksozoizomeraze (PHI) kod razičitih rasa svinja, Veterinarski glasnik, 41, 11-12, 912-5.

6. Juneja RK, Ghane B, Edfords-Ljilja J, Anderson E, 1983, Genetic variation at pig serum protein locus $\mathrm{PO} 2$ and its assignments to the PHI, Hal, S, H, PGD linkage group. Anim Blood groups Biochem Genet, 14, 27-36.

7. MacLennan DH, Phillips MS, 1992, Malignant hyperthermia, Science 256, 789-94. 
8. O’Brien PJ, Hua Schen, Corz RC, Xia Zhang, 1993, Use of DNA/based test for the mutation associated with porcine stress syndrome - malignant hyperthermia in 10000 breeding swine, JAVMA, 203, 842-51.

9. Rempel WE, Lu MY, Kandelgy SE, Kennedy FH, Irvin LR, Mickelson JR et al, 1993 Relative accuracy of the halothane challenge test and a molecular genetic test in detecting the gene for porcine stress syndrome, J Anim Sci, 71, 1395-9.

10. Sarač M, Jovanović S, Gagrčin M, 1996, PCR genotyping of the ryanodine receptor gene RYR1 in Yugoslav Meat Swine, Acta Veterinaria, 46, 185-92.

11. Schmolzl S, 1993, Sequence analysis of the 5'regulatory region and partial genomic structure of the porcine skeletal muscle ryanodine receptor (RYR1) gene, Molecular Biology, 12, 1-11.

12. Vogeli P, Bolt R, Fries R, Strazinger G, 1994, Co-segregation of the malignant hyperthermia and the Arg615-Cys615 mutation in the skeletal muscle calcium release channel protein in five European landrace and Pietrain pig breeds, Anim genet, 25, 59-66

\title{
POJAVA STRES SINDROMA (PSS) I MUTACIJE NA GENU ZA RIJANODIN RECEPTOR (RYR1) KOD EVROPSKE DIVLJE SVINJE (Sus scrofa ferus)
}

\author{
JOVANOVIĆ S, TRAILOVIĆ RUŽICA, SAVIĆ MILA i SARAČ M
}

\section{SADRŽAJ}

Pojava stres sindroma kod evropske divlje svinje ispitivana je primenom halotan testa i izvršena je genotipizacija na poziciji nukleotida 1843 u genu za rijanodin receptor (RYR1) korišćenjem PCR/restriktivnog endonukleaza testa.

Testirano je ukupno 56 životinja, starosti 5 meseci i prosečne telesne mase od $20 \mathrm{~kg}$. Od ukupno 56 jedinki 6 životinja je pokazalo $\mathrm{Hal}^{+}$(MHS) fenotip, 47 jedinki je imalo $\mathrm{Hal}^{-}$(MHN) fenotip, a tri jedinke nisu uopšte reagovale na $3 \%$ halotan ni posle 5 minuta uvođenja u narkozu i one su označene kao Halr fenotip. Genotipizacija na poziciji nukleotida 1843 u genu za rijanodin receptor pokazala je da su sve ispitivane jedinke, bez obzira na halotan status imale normalan RYR1 $\mathrm{C} / \mathrm{C}$ genotip.

Dobijeni rezultati ukazuju da se stres sindrom javlja i kod divljih svinja, mada postoji značajna modulacija pune ekspresije sindroma drugim faktorima. 